
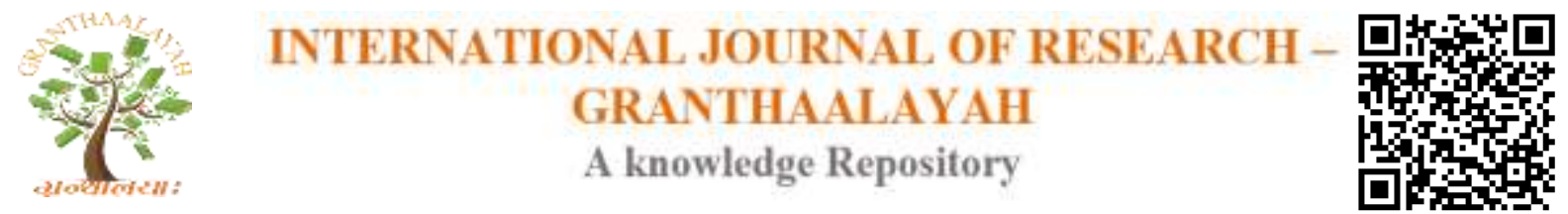

Management

\title{
FINANCIAL RELATIONS AMONG TIERS OF GOVERNMENT IN NIGERIA: AN OVERVIEW
}

\author{
S. Y. Ibrahim ${ }^{* 1}$, Umar Adamu ${ }^{2}$ \\ ${ }^{*}$ PhD, Department of Public Administration, University of Maiduguri, Nigeria \\ ${ }^{2}$ Department of Public Administration, Gombe State University, Nigeria
}

\begin{abstract}
The paper reviewed the nature of financial relations among the three tiers of government in Nigeria. It was identified that revenue allocation in every federation is a problem; as such each federation adopts its own strategies to contain the imbalance. It was discovered that several attempts were made, yet the problem still persists. This is because most federating units depend largely on the federal Account. Among the recommendations were review of the relevant sectoring of the constitution and creation of units of government should be based on viability rather than political consideration.
\end{abstract}

Keywords: Financial Relations; Government in Nigeria.

Cite This Article: S. Y. Ibrahim, and Umar Adamu. (2017). "FINANCIAL RELATIONS AMONG TIERS OF GOVERNMENT IN NIGERIA: AN OVERVIEW.” International Journal of Research - Granthaalayah, 5(7), 187-192. 10.29121/granthaalayah.v5.i7.2017.2120.

\section{Introduction}

In Nigeria, the problem which has not only defiled all past attempts at permanent solution but also a tendency for evoking high emotions on the part of all concerned each time it is brought forth for discussion or analysis, is the issue of revenue allocation. This is an issue that bas been politicized by successive administrations in Nigeria whether civilian or military. Indeed, in virtually all federations in which the constitution shares power between the central and regional or state governments and for each level to be within a sphere coordinate and independent (Wheares, 1953), enough resources need to be allocated to each to justify their existence. The nature and conditions of financial relations in federal systems particularly, that of Nigeria which has transfixed on a multi-ethnic society is crucial to her continuing existence. The Nigerian practice has assumed political, religious and social dimensions. According to experts, allotments of money (resources) must reflect social and economic conflicts between classes and groups. It is therefore, not surprising that, the basis of federal statutory revenue allocation has always been one of the most contentious and destabilizing factors in the Nigerian polity. 


\section{Theoretical Premise}

According to Dalton (1954), Public Finance is one of those disciplines which lie on the borderline between Economics and Politics. It should be noted that, what ever may be the origin of federation, be it aggregation or devolution, its establishment raises three problems:
a. How to allocate functions rationally,
b. How to allocate taxing powers
c. How to share revenue between and among levels of government.

On the other hand, Phillips (1975) observed that, revenue allocation formula must be accomplished via:
a. National Unity
b. Economic growth
c. Balanced development
d. Self sufficiency
e. High standard of living for the citizens.

Within the Nigerian context therefore, the hitch is how best to resolve these complex revenue allocation problems that will achieve the aforementioned objectives.

\section{Literature Review}

It is imperative to note that, Nigeria's revenue sharing debates, have revolved basically around three issues:

a. The relative proportions of federally collected revenue in the federation account that should be assigned to the centre, states, local governments as well as the "special funds" (vertical revenue sharing).

b. The appropriate formulae for the distribution of centrally devolved revenues among the states and the local governments (horizontal revenue sharing).

c. The percentage of federally collected mineral revenue that should be returned to the oil bearing states on the account of the principle of derivation and compensation for the ecological risks of oil production (Suberu, 1995).

In his contribution, Olopoenia (1998) opine that, since the oil boom in the early 1970s, the revenue allocation formula has been bedeviled by inconsistencies, a tendency of one of the parties in the consensual agreement to change the terms after the negotiations have been completed. Hence, according to him, the formula has been continually manipulated in the service of interregional and inter-ethnic cross-subsidization. Thus revenue allocation in Nigeria has not been " open covenants openly arrived at, rather they reflect the views of commissions, individuals or groups within the commissions - hence it proved unrealistic contributing to dislocations within the Nigerian state.

\section{Revenue Allocation in Nigeria}

The debate on Nigeria' s fiscal federalism and relations hinges on the fundamental question of who gets what of the national cake, when and how. Nigeria as a monolithic economy gets over 
$80 \%$ of its revenue from the crude oil and by virtue of the constitutional provision, this revenue must be disbursed to the three tiers of government. It is obvious that the nature and conditions of the financial relations in any federal system of government is crucial to the survival of such a system. In all federations, Nigeria inclusive, there is always constitutional wrangling or how resources should be shared among the constituent units. For instance, there are always poor and relatively rich units and in Nigeria such poor units often prefer a redistributive system of federal resource while the richer or more endowed states are in favour of more financial autonomy and revenue allocation based on the relative contribution of each constituent unit to the federal purse.

However, in order to overcome such difficulties in sharing the federal revenue, the federal government at various periods found it expedient to set up commissions and committees to articulate on the issue of proper revenue allocation formula. Such bodies established are presented below:

\begin{tabular}{|c|c|c|}
\hline $\begin{array}{l}\text { Commission } \\
\text { Committee or }\end{array}$ & Recommended Criteria & Other basic features of recommendation \\
\hline Phillipson, 1946 & $\begin{array}{l}\text { i) derivation. ii) Even } \\
\text { progress }\end{array}$ & $\begin{array}{l}\text { Balance after meeting central Government's } \\
\text { budgetary need allocated to regions }\end{array}$ \\
\hline $\begin{array}{l}\text { Hicks-Phillipson, } \\
1951\end{array}$ & $\begin{array}{l}\text { i) Derivation. ii) Fiscal } \\
\text { autonomy. iii) Needs, and } \\
\text { iv) National interest }\end{array}$ & $\begin{array}{l}\text { Proportion of specified duties and taxes } \\
\text { allocated to regions on the basis of } \\
\text { derivation, special grant-capitalization, } \\
\text { education and police }\end{array}$ \\
\hline Chick, 1951 & $\begin{array}{l}\text { i) Derivation. ii) Fiscal } \\
\text { autonomy. iii) Balanced } \\
\text { development. iv) Need }\end{array}$ & $\begin{array}{l}\text { Proportion of specified revenues distributed } \\
\text { on the basis of derivation. Creation of } \\
\text { distributable pool account (DPA) with fixed } \\
\text { regional proportional shares: North } 40 \% \text {, } \\
\text { West } 31 \% \text {, East } 24 \% \text { and Southern } \\
\text { Cameroun } 8 \% \text {. }\end{array}$ \\
\hline Binns, 1964 & $\begin{array}{l}\text { Same as above plus } \\
\text { financial comparability }\end{array}$ & $\begin{array}{l}\text { Composition of DPA relative share slightly } \\
\text { altered, North } 42 \% \text {, East } 30 \% \text {, West } 20 \% \text { and } \\
\text { Mid-West } 8 \% \text {. }\end{array}$ \\
\hline Diana 1968 & $\begin{array}{l}\text { i) Even development. ii) } \\
\text { Derivation. iii) Need. iv) } \\
\text { Minimum responsibility of } \\
\text { government }\end{array}$ & $\begin{array}{l}\text { Special grant account introduced, } \\
\text { recommended the establishment of } \\
\text { permanent planning and fiscal commission. } \\
\text { Recommendation rejected. }\end{array}$ \\
\hline $\begin{array}{l}\text { Decree No. } 13 \text { of } \\
1970\end{array}$ & $\begin{array}{l}\text { i) Population } 50 \% \text {. ii) } \\
\text { Equality of states } 50 \%\end{array}$ & $\begin{array}{l}\text { Export duties to states reduced from } 100 \% \text { to } \\
60 \% \text {. }\end{array}$ \\
\hline $\begin{array}{l}\text { Decree No. } 9 \text { of } \\
1971\end{array}$ & Same as above & $\begin{array}{l}\text { Transferred rents and royalties of offshore } \\
\text { petroleum mines from the states to the } \\
\text { Federal government. }\end{array}$ \\
\hline $\begin{array}{l}\text { Decree No.6 } \\
\text { of1975 }\end{array}$ & Same as above & $\begin{array}{l}\text { Onshore mining rents and royalties to states } \\
\text { reduced from } 45 \% \text { to } 20 \% \text {. Remaining } 80 \% \\
\text { to the DPA. Import duties on motor spirit } \\
\text { and tobacco to be paid } 100 \% \text { into the DPA. } \\
50 \% \text { of excise duties to e retained by Federal }\end{array}$ \\
\hline
\end{tabular}




\begin{tabular}{|c|c|c|}
\hline & & Government, $100 \%$ to DPA. \\
\hline $\begin{array}{l}\text { Decree No. } 15 \text { of } \\
1976\end{array}$ & Same as above & $\begin{array}{l}\text { Regional proportional share of DPA split } \\
\text { among the } 12 \text { new states, } 6 \text { Northern states } \\
\text { receive } 7 \% \text { each, East and Western states } \\
\text { share in accordance with relative population. }\end{array}$ \\
\hline Aboyade, 1977 & $\begin{array}{l}\text { (i) Equality of access } 25 \% \text {. } \\
\text { (ii) National minimum } \\
\text { standard } 22 \% \text {. (iii) } \\
\text { Absorptive capacity } 20 \% \text {. } \\
\text { iv) Independent revenue } \\
18 \% \text {. (v) Fiscal efficiency } \\
15 \%\end{array}$ & $\begin{array}{l}\text { Replaced DPA with Federation Account. } \\
\text { Fixed proportional share out of this account } \\
\text { between the Federal } 57 \% \text {, States } 30 \% \text {, Local } \\
\text { Government } 10 \% \text { and special fund } 3 \% \text {. } \\
\text { States and Local Government joint account } \\
\text { created. }\end{array}$ \\
\hline $1981 \mathrm{Act}$ & Same as above & $\begin{array}{l}\text { Federation Account to be shared. Federal } \\
\text { Government } 55 \% \text {, State Government } 30.5 \% \text {, } \\
\text { Local Government } 10 \% \text {, Special fund } 4.5 \% \text {. }\end{array}$ \\
\hline $\begin{array}{l}\text { Decree No. } 36 \text { of } \\
1984\end{array}$ & Same as above & $\begin{array}{l}\text { Federal Account to be shared: Federal } \\
\text { Government } 55 \% \text {, State Government } 32.5 \% \text {, } \\
\text { Local Government } 10 \% \text {, special fund } 2.5 \% \text {. }\end{array}$ \\
\hline $\begin{array}{l}\text { Danjuma } \\
\text { Commission } 1989\end{array}$ & Same as above & $\begin{array}{l}\text { Equality of state } 40 \% \text {, Population } 30 \% \text {, } \\
\text { Social development effort } 10 \% \text {, Tax effort } \\
10 \% \text {, Land mass } 10 \% \text {. }\end{array}$ \\
\hline $\begin{array}{l}\text { Decree No. } 49 \text { of } \\
1989\end{array}$ & $\begin{array}{l}\text { (i) Equality of Stats } 40 \% \text {. } \\
\text { (ii) Population } 30 \% \text {. (iii) } \\
\text { Internal Revenue Effort } \\
10 \% \text {. (iv) Landmass } 10 \% \text {. } \\
\text { (v)Social Development } \\
\text { Factor } 10 \%\end{array}$ & $\begin{array}{l}\text { Federation Account to be shared: Federal } \\
\text { Government } 47 \% \text {, State Government } 10 \% \text {, } \\
\text { Local Government } 15 \% \text {, Special fund } 8 \% \text {. }\end{array}$ \\
\hline $\begin{array}{l}\text { Decree No. } 3 \text { of } \\
\text { January } 1992\end{array}$ & Same as above & $\begin{array}{l}\text { Federation Account to be shared: Federal } \\
\text { Government } 50 \% \text {, State Government } 25 \% \text {, } \\
\text { Local Government } 20 \% \text {, Special fund } 5 \% \text {. }\end{array}$ \\
\hline 2009 & Same as above & $\begin{array}{l}\text { Federation Account to be shared: Federal } \\
\text { Government } 48.5 \% \text {, State Government } 24 \% \text {, } \\
\text { Local Government } 20 \% \text {, Special fund } 7 \% \text {. }\end{array}$ \\
\hline
\end{tabular}

Source: Compiled from various works of the Commissions, Committees and Conferences.

From the foregoing, it is apparent that in a federal state like Nigeria, a formula is usually devised to share the revenue of federation between the federal government and the governments of the component units. Revenue allocation is no doubt part of the processes of fiscal federalism. Typically the challenges of fiscal federalism in Nigeria hinge on the equity of the expenditure assignment and revenue-raising functions amongst the three tiers of government. The revenue sharing and expenditure assignment formula has been generally inadequate in addressing the needs and resource gaps among the three tiers of government. The strategy and institutional arrangement for redressing the mismatch have been approached incrementally over the years. Beginning with the era whereby a committee was appointed every five years to make recommendations regarding fiscal responsibilities among the tiers of government, the 1999 Constitution of the Federal Republic of Nigeria, under the third schedule, provide for the 
establishment of a body known as the Revenue Mobilization, Allocation and Fiscal Commission. While there is an apparent disconnects arising from expenditure and revenue responsibilities, this has not been as visible and controversial as the system of transfers or sharing of the national revenue. The sharing formula is based on arcane principles such as equality of states and landmass.

\section{Challenges of Revenue Allocation in Nigeria}

In the annals of federal countries, revenue sharing arrangements, and the sources of the federally collected revenue that form the subject of the sharing formula have remained largely unchanged. The sources which are not amenable to other units include import duties, mining rents, excise duties, export duties and royalties. The implication of this is that, since these sources of revenue are not amenable to the jurisdiction of the other units of government, the problem of revenue allocation has focused on not who should raise the taxes, but on how to share the proceeds, that is, the actual revenue collected by the federal government. The imbalance between functions and resources calls for higher level government (federal) to transfer revenues to the lower level governments. Graham (1964) in a perceptive work described such transfer as deficiency transfer or balancing. This is because, such transfer seeks to make up for the differences in the levels of functions devolved to the lower government and the resources available to it.

There is also revenue transfer principle which arises as a result of horizontal revenue sharing due to variations in revenue generation capacities of the federating units. This is called equalization transfer. The higher level government transfers money to the lower units of government in order for them (the lower units of government) make up for the differences between its internally generated revenue and those required for maintaining the minimum standard of services. The above transfers are what financial experts call intergovernmental grants in-aid.

The third principle which has been called differently by different scholars is simulation, incentive or conditional grants (Beak cited in Graham, 1964). This is also called categorical grants because they are desired for particular purposes. Whatever is the situation in a federation, no single federation has all its component parts equally developed, and therefore, the transfer of funds within a federation is a potent weapon in the hands of managers of the state especially in a plural society with diverse cleavages to satisfy hegemonic interests. On the other hand, transfers can help in ensuring that all parts of the federation have recourses to carry out their functions. This implies that, government can thus ensure that, revenue from resources located in a part of the country can be used for the benefit of all parts (Nyemutu Roberts, 2005). Thus revenue allocations can foster national integration. However, when misused, it can endanger political stability which can destabilize the political economy and tend to undermine efficacy of federalism in fostering political accommodation and economic development.

\section{Conclusion}

The history of sharing resources among the federating units in Nigeria confirms the existence of imbalance and all attempts made so far to change the statuesque have not yielded satisfactory results. This is because there are still cries from the two lower levels of government on inadequacy of fund from the federal account. 


\section{Recommendations}

a. The relevant sections of the Nigerian Constitution require review such as sharing of responsibilities among the tiers of government, revenue sharing and financial autonomy between the states and local governments.

b. The position of local governments is only in theory but in practice, they are not full tier of government. They completely rely on Federal financing.

c. Creation of more states and local governments should be on viability more than political favoritisms. This will reduce the incidence of total dependence on the federation account by the federating units.

\section{References}

[1] Dalton, H. (1954). Principles of Public Finance. Routledge and Kegan Paul, London.

[2] Federal Republic of Nigeria, 1999 Constitution, Federal Government press, Lagos.

[3] Graham, K. C. (1006). The Politics of Governing: A Comparative Introduction, Washington D.C., C. Q. Press.

[4] Olopoeria (1998). Cited " Odumuga Segun, The Impact of Corruption and Organized Crime in Nigeria' s Economic Development" in Lame, I. and Odekunle, F. (eds) Fighting Corruption and Organized Crime in Nigeria: Challenges for new Millenium, Ibadan: Spectrum Books.

[5] Phillips, A. (1975). Revenue Allocation in Nigeria. Nigerian Journal of Economic and Social Studies, Vol.17, No.2, July.

[6] Suberu, R. T. (2015). Conflict and Accommodation in the Nigerian Federation 1993 - 2003. In Gana, A. T. and Omelle, Y. B. C. (eds) Democratic Rebirth in Nigeria Vol.one 1999-2003, Abuja: AFRIGOV.

[7] Wheares (1953). Federal Government: Third Edition, Oxford University Press.

*Corresponding author.

E-mail address: ysaalah@ yahoo.com 